\title{
Ownership characteristics and crop selection in California cropland
}

\author{
Analyses of cropland ownership patterns can help researchers prioritize outreach efforts and tailor \\ research to stakeholders' needs.
}

by Luke Macaulay and Van Butsic

A griculture plays a major role in shaping California landscapes, and land ownership characteristics are an important predictor of economic decision-making, conservation practices and recreational use (Ferranto et al. 2013; Macaulay 2016). As such, improved information on agricultural land ownership is necessary for continued improvements in agricultural efficiency and environmental protection. Although California has a robust history of collecting agricultural statistics at the county scale in county agricultural reports, these reports do not include information on the ownership characteristics of cropland in their county, such as average property size, the distribution of ownership, and what kind of crops were planted together on individual properties.

Improvements in remote sensing technologies have allowed for increasingly accurate maps that specify where crops are planted, and advances in geographic information systems processing capacity is allowing for owner-level analysis of agricultural land use. This study presents a novel analysis that draws on publicly available satellite-based cropland data and a spatially explicit land ownership database that was developed by the authors.

The U.S. Department of Agriculture (USDA) Census of Agriculture surveys growers every 5 years and provides substantial summary information on farms by acreage range and crop type. Our method supplements that data by providing information at the property

\section{Abstract}

Land ownership is one of the primary determinants of how agricultural land is used, and property size has been shown to drive many land use decisions. Land ownership information is also key to understanding food production systems and land fragmentation, and in targeting outreach materials to improve agricultural production and conservation practices. Using a parcel dataset containing all 58 California counties, we describe the characteristics of cropland ownership across California. The largest 5\% of properties — with "property" defined as all parcels owned by a given landowner - account for $50.6 \%$ of California cropland, while the smallest $84 \%$ of properties account for $25 \%$ of cropland. Cropland ownership inequality (few large properties, many small properties) was greatest in Kings, Kern and Contra Costa counties and lowest in Mendocino, Napa and Santa Clara counties. Of crop types, rice properties had the largest median size, while properties with orchard trees had the smallest median sizes. Cluster analysis of crop mixes revealed that properties with grapes, rice, almonds and alfalfa/ hay tended to be planted to individual crops, while crops such as grains, tomatoes and vegetables were more likely to be mixed within a single property. Analyses of cropland ownership patterns can help researchers prioritize outreach efforts and tailor research to stakeholders' needs.

level, which we define as all parcels owned by a given landowner. This method allows the generation of ownership summary statistics and measures of inequality by county and by crop. The method also provides new
Online: https://doi.org/10.3733/ ca.2017a004

Almond orchards in Stanislaus County. Analyzing land ownership distribution in California by crop type and property size can help scientists and extension professionals shape research programs according to the needs of local growers. 
information on crop mixes by property, and presents the complex information in graphs and figures for ease of comprehension and further analysis.

Information about the property-size distribution and use of agricultural land at the property level is useful in assessing technology adoption, fragmentation of land, pesticide application, wildlife connectivity and many other issues (Brodt et al. 2006; Greiner and Gregg 2011; Sunding and Zilberman 2001). Data on agricultural landownership patterns can also help answer a host of important questions such as the characteristics of properties that are planted with a particular crop; variation in ownership patterns across counties; and cropping combinations. Finally, ownership information also can be useful for organizations providing technical and conservation support on a landscape scale.

\section{Methods}

\section{Ownership data}

The study describes California's cropland. Private cropland includes land owned by private companies, individuals, nongovernmental organizations, and American Indian tribes (fig. 1A). Analyses were performed using two main datasets, a spatially explicit land ownership database and the USDA National
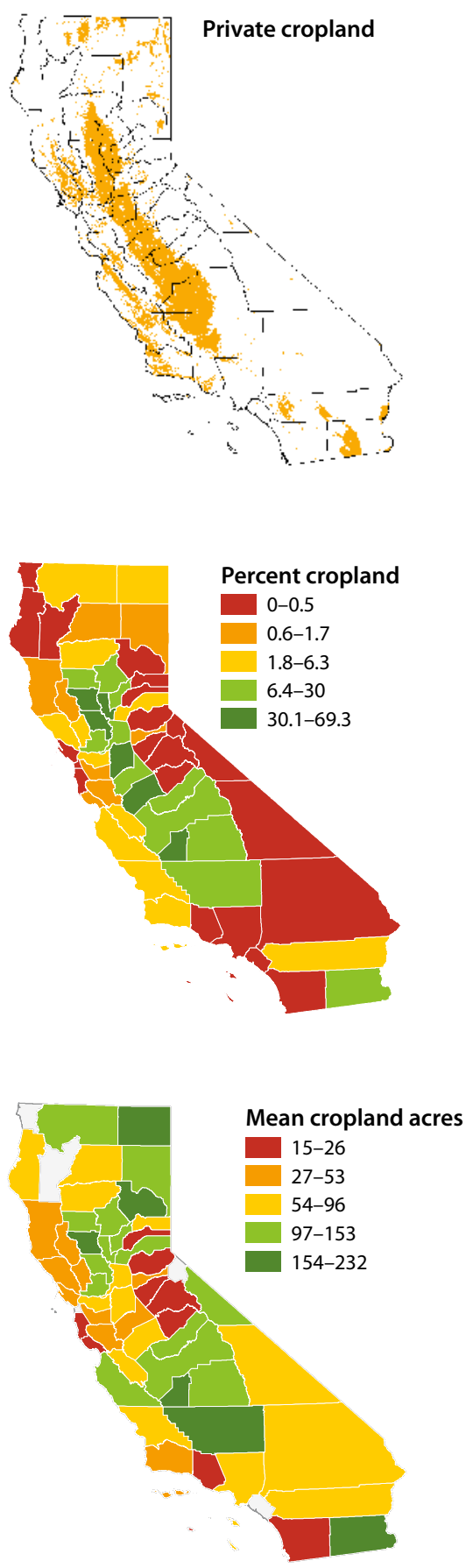
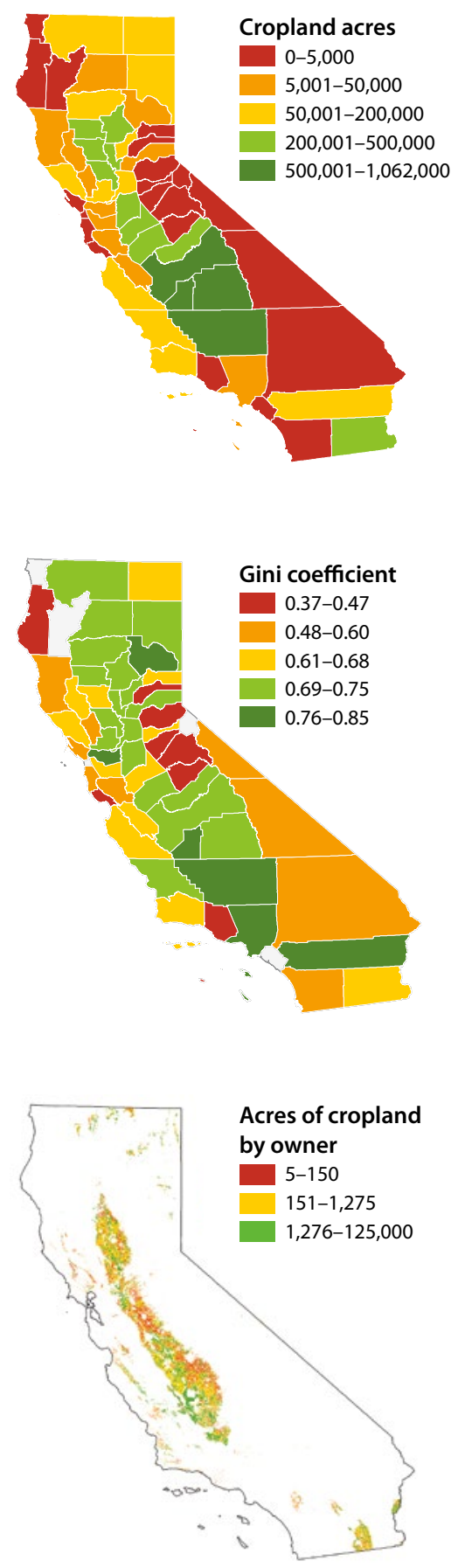
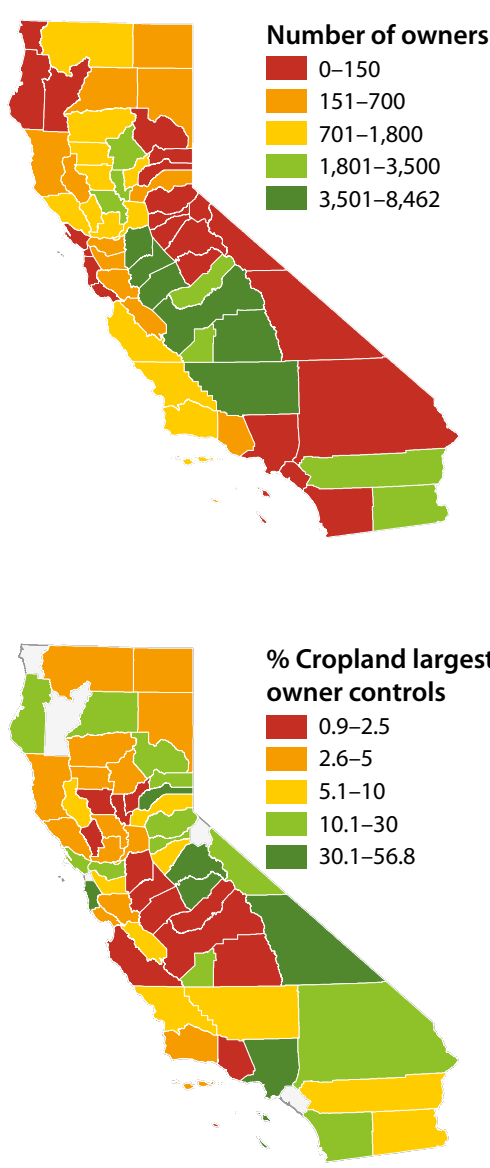

Fig. 1. Descriptive measures of California cropland by count. Counties with gray shading have one or fewer cropland owners. 
Agricultural Statistics Service (NASS) Cropland Data Layer (CDL).

Parcel data was assembled for all 58 California counties. Parcel data with ownership information for 49 counties was derived from Boundary Solutions Inc., with the remaining nine counties assembled by contacting individual county governments. These county parcel data sets came from varying years, with 49 counties from 2011 to 2015 and nine counties from 2005 to 2010. Although this does not provide a completely current ownership map at a single point in time, most counties have recent data. Additionally, studies indicate that only $0.5 \%$ of U.S. farmland is sold annually, suggesting that the impact of land sales on the results presented here should be small (Sherrick and Barry 2003). In considering the ownership data presented here, it is also important to note that a sizeable percentage of landowners of California agricultural land (37\%) are non-farming owners and rent or lease out their land to others (Bigelow et al. 2016).

To develop an ownership map for some counties, we merged data from separate files (nonspatial ownership information and spatial polygons) using a common field of assessor parcel numbers (APNs). After assembling county parcel maps for the entire state, we then dissolved parcels by owner name to remove interior borders of parcels owned by the same entity and to calculate total area under each ownership, which we refer to as a property. For analyses that used the county as the unit of analysis (section titled "County cropland ownership," table 1 and fig. 1), the analysis only considered ownership within that county. For all other analyses, ownerships were combined across all counties, so that land in multiple counties with a single owner was considered to be a single property.

Several counties had incomplete ownership data, and this initial mapping resulted in approximately $8 \%$ of the state's area with unknown ownership information ( $\sim 2.25$ million acres). To reduce the area of unknown ownership, we overlaid three separate ownership maps that cover public land and conservation easements and used these maps to assign ownership to parcels that did not have ownership information from original parcel data (CCED 2015; CDFFP 2014; CPAD 2015). This process reduced unknown ownership to approximately $2.7 \%$ of California's total land area ( 2.85 million acres) and 4.4\% ( 385,000 acres) of California's cropland. Although unknown ownership is likely to be private, it was omitted from calculations. Ownerships were further categorized as public or private using 80 search terms in the ownership name field. The final ownership map was composed of approximately 543,495 properties greater than 5 acres across the state of California.

\section{Cropland data}

The USDA CDL was used to assess crops grown in California. The CDL is a raster, geo-referenced, cropspecific land cover data layer with a ground resolution of 30 meters. It is produced using satellite imagery from the Landsat 8 OLI/TIRS sensor and the Disaster Monitoring Constellation DEIMOS-1 and UK2 sensors collected during the 2013 growing season. The CDL methodology accommodates single and double crop plantings by using Farm Service Agency Common Land Unit data as training data. The CDL estimates occurrence of 99 different crops, which were condensed by the authors to 14 broad crop categories. In making this classification, any single crop with more than 250,000 acres statewide was left as an individual crop type (see supplemental table 1 at ucanr.edu/u. cfm?id=182). The crop type grown on individual properties was determined by overlaying the CDL with the spatial ownership database. The number of pixels of each particular crop type occurring within each ownership boundary was calculated and converted to acres. The results provided in this analysis pertaining to crop category (tables 2 and 3) indicate the acres of crops grown within a property (rather than the total property size). Discussion of county-level results focuses on counties with more than 5,000 acres of cropland and more than 250 owners.

\section{Callifornia Land Use and Ownership Portal}

$\mathrm{T}$ he authors, in collaboration with UC Agriculture and Natural Resources' IGIS program, have also developed the California Land Use and Ownership Portal, which has an interactive map displaying the information contained in this article and much more. The portal allows users to view each county's cropland ownership and planting statistics as well as information about the natural vegetation found in the county. This tool is useful for gaining a broad understanding of land use and land ownership at the county level in California. The portal allows users to export images, figures and charts of land ownership, crop cover and natural vegetation. You can access it at http://callands.ucanr.edu.

The CDL includes an accuracy assessment that includes the user's accuracy and producer's accuracy (USDA-NASS 2014). The user's accuracy indicates the probability that a pixel from the CDL classification matches the ground truth data, while the producer's accuracy indicates the probability that a ground truth pixel will be correctly mapped. We weighted the accuracies for all crop types based on their percentage of total cropland, resulting in a weighted average accuracy of $82 \%$ for both user and producer accuracy.

To reduce the effect of this error in the CDL, this study excluded properties smaller than 5 acres and those composed of less than 5\% cropland, under the assumption that production of less than 5 acres, while possible, was not oriented towards production agriculture and had a higher likelihood of being a remote sensing error. This exclusion reduced the overall private cropland area by 491,522 acres or $5.9 \%$, resulting in a total private cropland area in this study of 7,872,543 acres. The number of owners was reduced more drastically, dropping from 112,419 to 68,699 , a reduction of 
$38.9 \%$. Due to these reductions, we believe the estimates in this study to be conservative, while minimizing the effect of remote sensing errors.

While we believe that our method of combining ownership and crop data produces a very high-quality map, some characteristics of the data influence the results and some error likely remains. Acreage statistics are greatly affected by the cutoff value of the minimum size of cropland ownership (in this case 5 acres). Raising or lowering the minimum size farm in the dataset increases or decreases the mean and median statistics correspondingly. After evaluating various cutoff values, we felt that 5 acres was an appropriate cutoff that would include many of the small farmers in California, but minimize impacts of remote sensing error.

Another trend occurring in some parts of California that could affect results is the separation of large farming operations into multiple corporate entities to reduce liability risks. Although this practice would lead to a reduction in the mean acreage values, we don't expect this practice to be widespread enough to significantly alter the results presented here. Additional sources of error include those arising from county level parcel data, from combining properties with very similar names (as noted in the methods section below) and the aggregation of ownership maps over multiple years.

Additionally, the crop data is a snapshot in time. 2013 was a drought year, with likely many more acres left fallow than in a wetter year. Our analysis estimates fallow land at a total of 1.14 million acres. By comparison, a previous analysis (NASA 2015) of 2011, a wetter year, estimated 500,000 acres of fallowed land. As such, our results should be viewed as reflecting dry year conditions, with reduced acreage planted to crops compared with an average or wetter year.

\section{Analytical methods}

Several analytical techniques are described that were used to prepare this data for analysis, including matching similar owner names, calculating equality metrics, and clustering properties based on planted crops.

Matching similar ownership names. In some cases, there were minor variations in owner names arising from different data entry protocols by county, punctuation standards, abbreviations and typographical errors (for example "California State University" and "California State Univ"). To correct for these inconsistencies, we used the Jaro-Winkler distance measure (using a weight of $p=0.08$, and a cutoff distance value of $<0.05$ for statewide matching and $<0.06$ for county-level matching) to link records that have slightly different ownership names (Jaro 1989; Winkler 1990). The algorithm linked 14,459 records from the original dataset of 119,226 private cropland ownerships. These linked records were combined and aggregated into 7,665 records. The combined records were evaluated for accuracy and resulted in an estimated

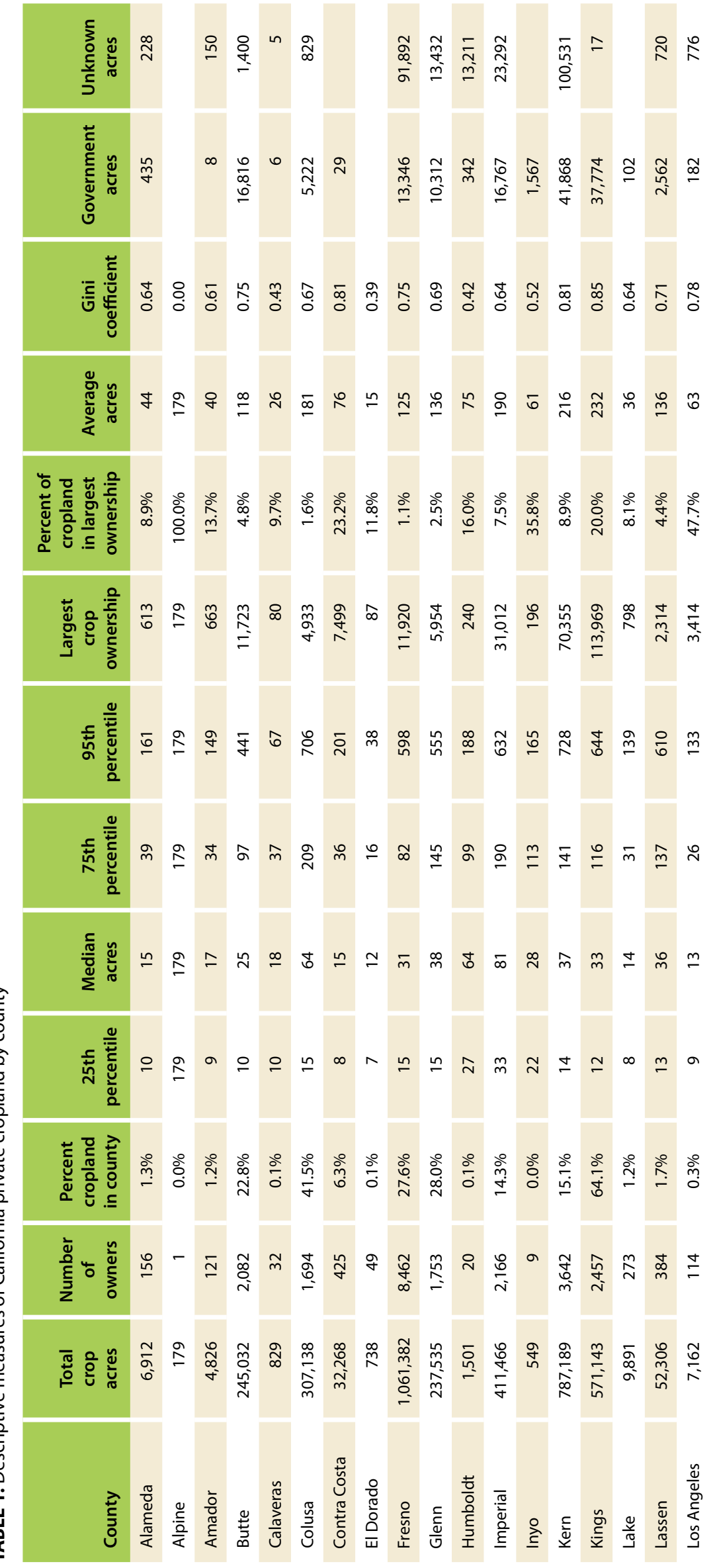




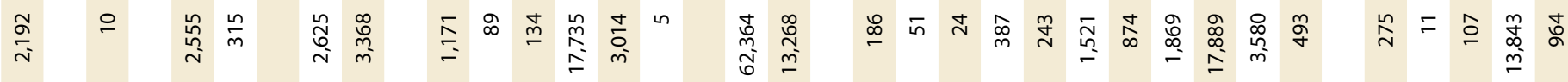

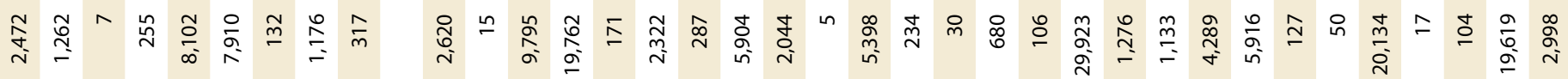

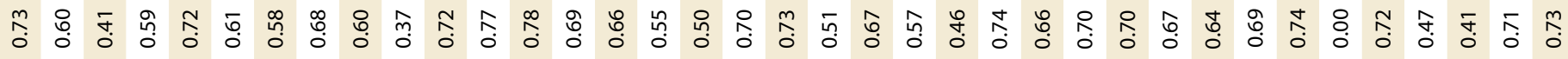

舟足ニ

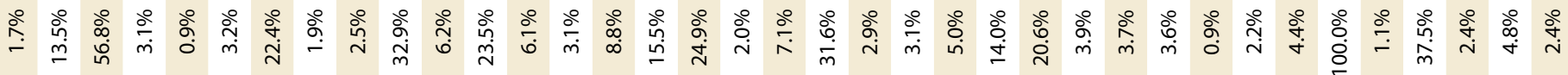

学

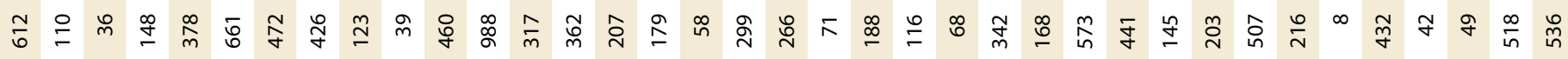

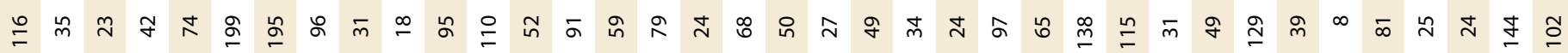

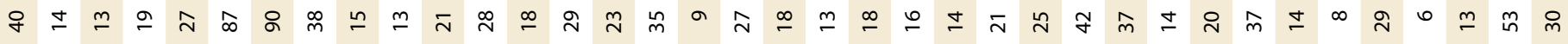

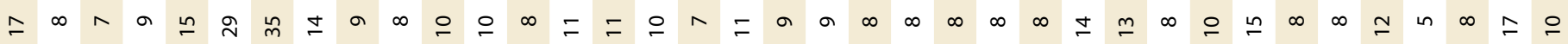

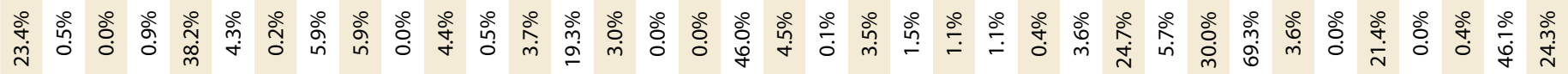

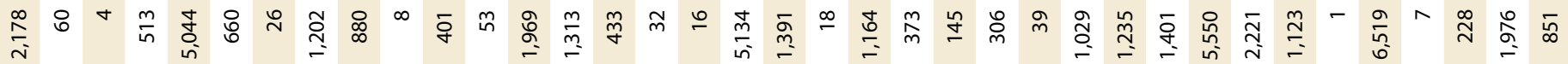

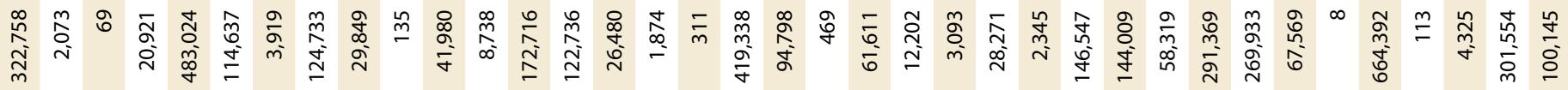

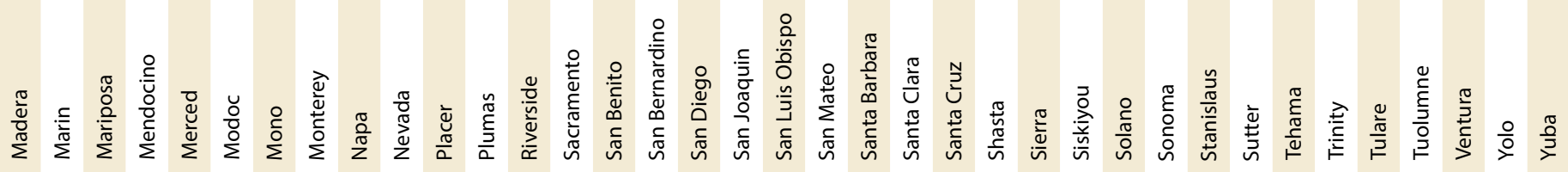


error rate of $4 \%$ based on a random sample of 100 linked names. Because only $12 \%$ of records were identified for combining, in the context of the entire dataset the error rate of mistakenly combined records is $0.23 \%$ of all records. After this processing, the total number of owners with any cropland was 112,419.

Evaluating land concentration. For each county, we used the assembled ownership data to calculate the Gini coefficient of land ownership. The Gini coefficient

TABLE 2. Acres of government-owned cropland by crop type

\begin{tabular}{|c|c|c|c|c|c|c|}
\hline & Federal & State & Local & $\begin{array}{l}\text { Special } \\
\text { district }\end{array}$ & $\begin{array}{c}\text { Miscellaneous } \\
\text { government }\end{array}$ & $\begin{array}{l}\text { Total } \\
\text { acres }\end{array}$ \\
\hline Alfalfa/hay & 15,252 & 12,853 & 16,538 & 2,326 & 3,474 & 50,444 \\
\hline Almonds & 2,358 & 1,169 & 3,363 & 1,363 & 139 & 8,393 \\
\hline Corn & 408 & 3,429 & 1,597 & 600 & 10 & 6,044 \\
\hline Cotton & 1,287 & 139 & 1,116 & 1,594 & 1,856 & 5,992 \\
\hline Fallow & 48,222 & 46,704 & 25,325 & 34,121 & 6,303 & 160,675 \\
\hline Fruit trees & 1,593 & 416 & 1,228 & 268 & 73 & 3,579 \\
\hline Grain crops & 33,413 & 1,868 & 7,674 & 1,491 & 1,329 & 45,775 \\
\hline Grapes & 312 & 1,024 & 2,347 & 709 & 19 & 4,410 \\
\hline $\begin{array}{l}\text { Other tree } \\
\text { crops }\end{array}$ & 1,344 & 1,194 & 1,094 & 619 & 1 & 4,252 \\
\hline Rice & 520 & 1,469 & 667 & 854 & 7 & 3,517 \\
\hline Tomatoes & 916 & 162 & 538 & 699 & 1,170 & 3,484 \\
\hline $\begin{array}{l}\text { Vegetables/ } \\
\text { fruit }\end{array}$ & 4,810 & 1,435 & 1,240 & 771 & 634 & 8,891 \\
\hline Walnuts & 1,016 & 375 & 1,214 & 1,011 & 264 & 3,881 \\
\hline Winter wheat & 1,849 & 2,478 & 5,500 & 3,422 & 1,382 & 14,631 \\
\hline Total acres & 113,302 & 74,715 & 69,440 & 49,846 & 16,663 & 323,967 \\
\hline
\end{tabular}

is a measure of statistical dispersion that is commonly used as a measure of inequality. The coefficient values range from 0 to 1 , where a value of 0 signifies perfect equality (every person owns the same amount of land) and a value near 1 equals perfect inequality (one individual owns all the land). The R package ineq (Zeileis 2014) was used to calculate Gini coefficients for each county.

Clustering of crop types. We used hierarchical clustering to evaluate combinations of crops planted together on a single property. Fourteen variables (representing 14 crop categories) were created corresponding to the fraction of a property planted to a given crop category. We then standardized the values of these variables by subtracting the mean and dividing by the standard deviation. We ran a hierarchical cluster analysis that compares the dissimilarity of the 68,699 ownerships being clustered. In this method, each object is initially assigned to its own cluster and then the algorithm proceeds by joining the two most similar objects, continuing iteratively through the dataset until there is just a single cluster. We selected the Ward's minimum variance method, which seeks to find compact spherical clusters using Euclidean distance, to cluster the ownerships based on mixes of crops present. We used the fastcluster package to implement the clustering algorithm, which has memorysaving routines and allowed for this analysis without creating a distance matrix (Müllner 2013). Caution should be taken in extrapolating 2013 crop mixes to other years, given that the analysis was performed during a drought year and farmers may have been making crop adjustments.

TABLE 3. Descriptive statistics of crop types

\begin{tabular}{|c|c|c|c|c|c|c|c|c|c|c|c|}
\hline $\begin{array}{l}\text { Crop } \\
\text { category }\end{array}$ & $\begin{array}{l}\text { Total } \\
\text { acres }\end{array}$ & $\begin{array}{c}\text { Number } \\
\text { of } \\
\text { owners }\end{array}$ & $\begin{array}{c}\text { 25th } \\
\text { percentile }\end{array}$ & $\begin{array}{l}\text { Median } \\
\text { acres }\end{array}$ & $\begin{array}{c}\text { 75th } \\
\text { percentile }\end{array}$ & $\begin{array}{c}\text { 95th } \\
\text { percentile }\end{array}$ & $\begin{array}{c}\text { Largest } \\
\text { crop } \\
\text { ownership }\end{array}$ & $\begin{array}{c}\text { Percent } \\
\text { of crop } \\
\text { in largest } \\
\text { ownership }\end{array}$ & $\begin{array}{l}\text { Average } \\
\text { acres }\end{array}$ & $\begin{array}{l}\text { Coefficient } \\
\text { of variation }\end{array}$ & $\begin{array}{l}\text { Gini } \\
\text { coefficient }\end{array}$ \\
\hline Alfalfa/hay & $1,305,745$ & 21,086 & 4.0 & 12.7 & 52.9 & 254.8 & 16,399 & $1.3 \%$ & 61.9 & 3.7 & 0.76 \\
\hline Fallow & $1,141,035$ & 25,265 & 3.6 & 8.9 & 25.4 & 151.2 & 60,683 & $5.3 \%$ & 45.2 & 10.3 & 0.80 \\
\hline Almonds & $1,066,419$ & 24,120 & 2.7 & 8.2 & 28.7 & 172.6 & 39,193 & $3.7 \%$ & 44.2 & 7.4 & 0.80 \\
\hline Grapes & 761,517 & 18,015 & 4.0 & 10.7 & 31.8 & 158.0 & 6,794 & $0.9 \%$ & 42.3 & 3.5 & 0.76 \\
\hline Grain crops & 674,197 & 13,214 & 3.3 & 12.0 & 46.9 & 205.1 & 12,153 & $1.8 \%$ & 51.0 & 3.4 & 0.75 \\
\hline Rice & 557,149 & 2,599 & 39.6 & 118.8 & 258.3 & 696.1 & 10,543 & $1.9 \%$ & 214.4 & 1.9 & 0.61 \\
\hline $\begin{array}{l}\text { Winter } \\
\text { wheat }\end{array}$ & 410,790 & 8,994 & 2.9 & 10.2 & 39.1 & 183.9 & 8,866 & $2.2 \%$ & 45.7 & 3.3 & 0.76 \\
\hline Fruit trees & 391,900 & 14,168 & 3.1 & 8.5 & 23.1 & 103.0 & 5,283 & $1.3 \%$ & 27.7 & 3.5 & 0.73 \\
\hline Walnuts & 313,258 & 11,284 & 2.2 & 6.7 & 22.7 & 115.2 & 8,225 & $2.6 \%$ & 27.8 & 3.9 & 0.75 \\
\hline Cotton & 277,694 & 2,374 & 5.8 & 30.5 & 98.3 & 340.4 & 56,602 & $20.4 \%$ & 117.0 & 10.3 & 0.78 \\
\hline Tomatoes & 272,021 & 4,051 & 3.3 & 14.7 & 69.8 & 299.7 & 3,179 & $1.2 \%$ & 67.1 & 2.3 & 0.74 \\
\hline Corn & 248,064 & 3,556 & 4.7 & 20.9 & 67.2 & 249.4 & 11,164 & $4.5 \%$ & 69.8 & 3.8 & 0.73 \\
\hline $\begin{array}{l}\text { Vegetables/ } \\
\text { fruit }\end{array}$ & 247,844 & 4,891 & 4.7 & 15.8 & 55.3 & 203.3 & 3,655 & $1.5 \%$ & 50.7 & 2.2 & 0.70 \\
\hline $\begin{array}{l}\text { Other tree } \\
\text { crops }\end{array}$ & 203,908 & 5,779 & 1.6 & 5.3 & 16.9 & 134.8 & 14,275 & $7.0 \%$ & 35.3 & 6.8 & 0.84 \\
\hline
\end{tabular}




\section{California crop- land ownership characteristics}

Approximately $96 \%$ of California cropland is privately owned, followed by $1.4 \%$ federal, $0.9 \%$ state, $0.8 \%$ local and $0.6 \%$ special districts (e.g., irrigation districts). Of the government-owned land, $50 \%$ is fallow, $16 \%$ is alfalfa or hay and $14 \%$ is grain crops, with all other crops making up less than $5 \%$ of the total (table 2).

In 2013, there were approximately 7.87 million acres of private cropland in California greater than 5 acres or $5 \%$ of an owner's property, made up by approximately 68,699 owners. The largest $1 \%$ of cropland properties (the 687 properties larger than 1,277 acres) accounted for $26.5 \%$ of California's cropland. The largest $5 \%$ of properties $(3,435$ properties that are larger than 477 acres) account for just over half (50.6\%) of California's cropland. The remaining $95 \%$ of properties $(65,370$ properties) compose the remainder $(49.4 \%)$ of the state's cropland. The $25 \%$ of California cropland composed of the smallest properties is made up of 57,490 properties, $84 \%$ of all owners, and these properties are less than 152 acres (table 4 and fig. 2). The median acreage of properties was 29.8 acres and mean acreage was 120.7 acres.

\section{County cropland ownership}

We calculated metrics of cropland ownership on a county basis, including an analysis of equality of ownership, represented by the Gini coefficient. Fresno, Kern and Tulare counties were the three counties with the largest overall area of cropland. Of the three, Kern County has the fewest number of properties $(3,642$ versus $>6,500$ ). Two other counties, Sutter and Kings counties, were notable for their land area being dominated by cropland, with over $64 \%$ of their land area composed of private cropland, with the next highest amount at $46 \%$ in Yolo and San Joaquin Counties. Median size of cropland property tended to be largest in the rural corners of California, with the highest values in Imperial and Modoc counties (> 80 acres).

TABLE 4. Frequency table of ownership of California cropland based on size class

\begin{tabular}{|c|c|c|c|c|c|c|}
\hline $\begin{array}{l}\text { Size category } \\
\text { (acres) }\end{array}$ & Total acres & $\begin{array}{l}\text { Percent of } \\
\text { total acres }\end{array}$ & $\begin{array}{l}\text { Cumulative } \\
\text { sum of acres }\end{array}$ & $\begin{array}{c}\text { Number of } \\
\text { owners }\end{array}$ & $\begin{array}{l}\text { Percent of } \\
\text { total owners }\end{array}$ & $\begin{array}{c}\text { Cumulative sum } \\
\text { of owners }\end{array}$ \\
\hline $5-10$ & 97,056 & $1.2 \%$ & 97,056 & 13,327 & $19.4 \%$ & 13,327 \\
\hline $10-25$ & 301,931 & $3.6 \%$ & 398,988 & 18,413 & $26.8 \%$ & 31,740 \\
\hline $25-50$ & 423,983 & $5.1 \%$ & 822,970 & 11,853 & $17.3 \%$ & 43,593 \\
\hline $75-100$ & 305,583 & $3.7 \%$ & $1,475,985$ & 3,572 & $5.2 \%$ & 52,738 \\
\hline $100-250$ & $1,391,963$ & $16.8 \%$ & $2,867,948$ & 8,875 & $12.9 \%$ & 61,613 \\
\hline $250-500$ & $1,367,857$ & $16.5 \%$ & $4,235,805$ & 3,934 & $5.7 \%$ & 65,547 \\
\hline 1,000 & $1,459,906$ & $17.6 \%$ & $5,695,711$ & 2,106 & $3.1 \%$ & 67,653 \\
\hline$>10,000$ & 558,856 & $6.7 \%$ & $8,298,024$ & 20 & $0.03 \%$ & 68,699 \\
\hline
\end{tabular}

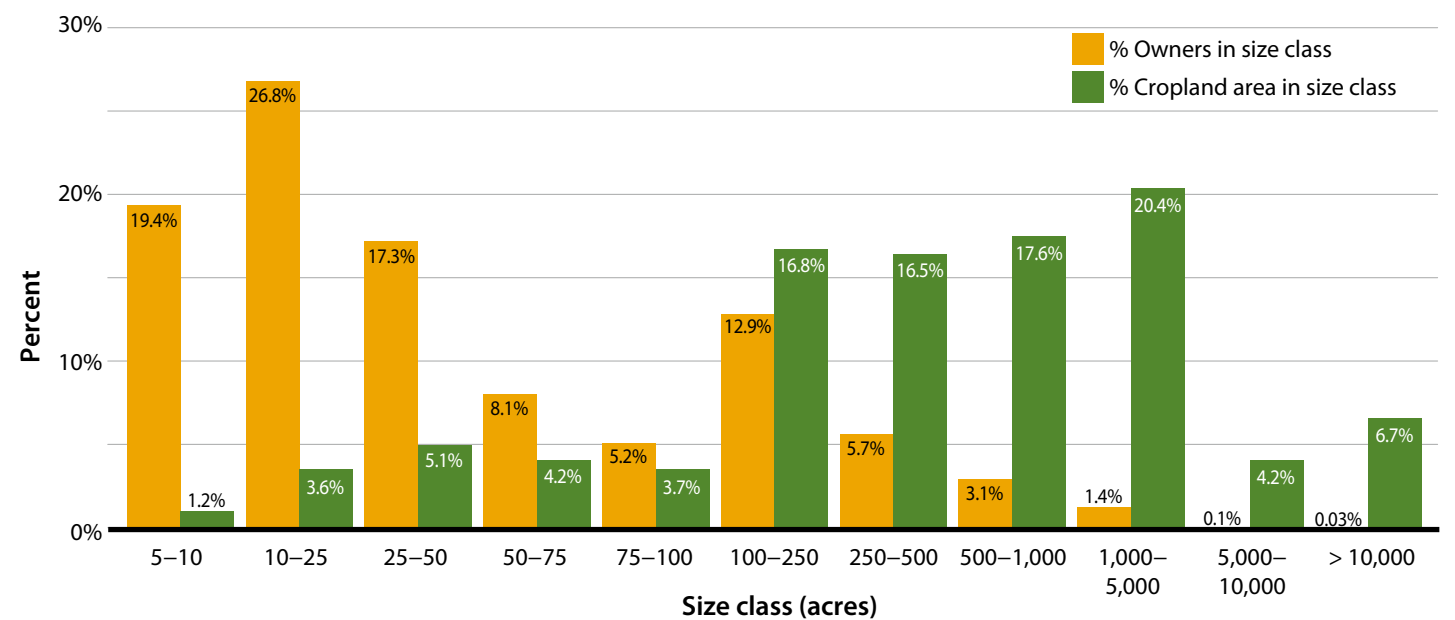

More urban and tourism-focused counties (Los Angeles, Lake and Sonoma counties) tended to have lower median property size. Equality of cropland ownership, however, was not well-predicted by whether a county is rural or developed; rather, it tended to be most associated with the size and number of the largest landowners in the county or regulations implementing a minimum parcel size. Kings County has the most unequal cropland ownership, followed by Kern and Contra Costa counties. The most equal cropland ownership (of counties with $>5,000$ acres of private cropland) was found in Santa Clara, Napa and Mendocino counties (table 1 and fig. 1).

\section{Crop types}

Many crops had similar ownership characteristics with a few exceptions. Rice and cotton had large average acreages planted, while fruit trees, walnut trees and other tree crops had small average size plantings (table 3 and fig. 3).

Among properties growing rice, the average acres planted to rice were far larger (214 acres) than the average acreages grown in all other crop categories. There were also few properties that planted small areas of
Fig. 2. Distribution of number of owners and percent of private cropland ownership greater than 5 acres in particular size classes of ownership. 
rice; the 25th percentile of rice acres planted was 40 acres, more than six times larger than the equivalent measure for any other crop type. Properties planted with cotton in 2013 had the second highest average (117 acres), but the median acreage of cotton properties was similar to other crops. The metric that tends to set cotton apart from rice is its much higher maximum acres grown on a single property $(\sim 56,600$ acres). Rice and cotton had comparatively few properties planted, ranking 13th and 14th in number of owners across 14 crop categories, yet they ranked 6th and 10th in acres planted out of the crop categories.

The crop categories of fruit trees, walnuts and other tree crops were notable for their comparatively small ownerships. Mean ownership was between 27 and 35 acres, and median values were below 8.45 acres. While two other crop types, almonds and fallow land, had median values around 8 acres, their average values were comparatively larger.

The year 2013 was the second year of the recent and ongoing drought in California, and approximately 25,265 owners had over a million acres left fallow, with 45 acres being the average area left fallow. Nearly 60,000 of those acres were left fallow by a single property owner in Kings, Kern and Tulare counties, an area where crops grown are highly dependent on irrigation.

Land planted with rice, which had the highest average acreage planted, also had the most equal distribution of land, in part because there were relatively few small properties. The most unequal ownership came in the other tree crops category, which is composed of $82 \%$ pistachios, $1 \%$ pecans and $17 \%$ all other tree crops. In that crop category, a single ownership that was planted with pistachios accounted for $7 \%$ of that crop category's area. This, combined with an abundance of small owners (evidenced by the lowest median ownership size of all crop categories), led to a high inequality measure.

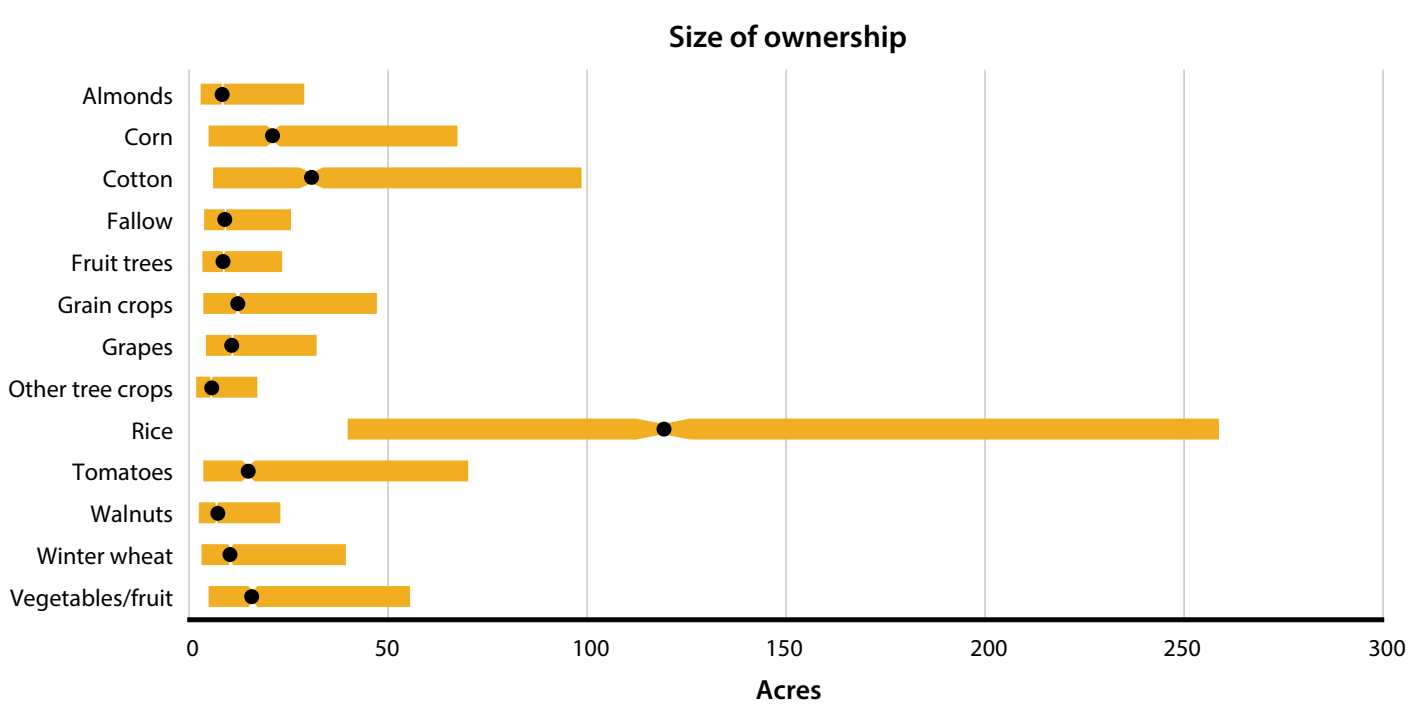

Fig. 3. Measures of acres planted by individual owners by crop type. Median represented by black dot, 1 st and 3rd quartile value at outer edge of boxes.

\section{Crop mixes}

Many landowners or their tenants plant multiple crops, either in rotation or as market demands shift. We used our database to calculate typologies of properties based on the similarities of crops that were planted together. Seven crop clusters were identified that yield interesting insights into how farmers specialize or mix crops (fig. 4). Three clusters tended to mix crops or orchards, with no single category composing more than half of the property area, while four clusters tended to specialize in a particular crop type with more than $79 \%$ planted in a single crop type. Many grape, rice, almond and alfalfa/hay producers tended to focus the majority of their plantings in their primary crop. Of the three clusters that mixed crops, one was mixtures of fruit trees, almonds and walnuts; the second was dominated by fallow land and a mixture of other crops; the third group was very diverse, and tended towards a comparatively even mixture of grain crops, tomatoes, alfalfa/ hay and fallow land. Of the farmers who specialized in single crops, those who grew grapes had the strongest specialization, followed by rice, alfalfa/hay and almonds.

\section{Implications for research and extension}

Agricultural statistics are crucial to decision-making, to improving agricultural efficiency and to protecting the environment. Improvements in remote sensing technologies along with the availability of parcel data allow researchers to present agricultural statistics in new ways. We do that here and show, to our knowledge for the first time, how land ownership is distributed for multiple crops throughout the state. We do not comment here on whether this ownership arrangement is efficient, just or fair.

From the perspective of resource agencies and Cooperative Extension, these ownership patterns present opportunities for tailoring research and extension programs to their desired audience. For example, knowledge of the average size and distribution of cropland ownership in a particular type of crop can assist researchers developing more efficient harvest methods geared towards a particular sized parcel, or in prioritizing outreach activities and methods of communication. In terms of outreach, natural resource 
professionals seeking to increase adoption of best practices in particular counties or for certain crop types can benefit from this knowledge. For example, in crop types dominated by a few large properties, individual outreach may be an appropriate method of extension given the disproportionate area of cropland affected. Alternatively, crops dominated by many small properties like fruit trees or walnuts will likely require efforts utilizing mass communication tools that can reach thousands of owners. For crops with comparatively low variation in ownership size (rice and tomatoes), outreach agencies may be able to reach a broad audience by focusing on challenges facing an average sized farm. Crops with wide variation in property size (e.g., almonds, other tree crops and properties with fallow land), may require an approach that reaches owners of small, medium and large properties. While the vegetables/fruit category exhibits low variation in property size owned, it contains the widest variation of crop types, requiring a large diversity of subject matter experts that can be devoted to relatively similar sized properties.

The analysis of crop mixes yields insights into guiding research and extension approaches, as well as information for equipment or seed sellers. Knowing that grapes, rice, alfalfa/hay and almonds all tended towards specialization suggests that specialized outreach may be most effective. Crop types that tend to be mixed may warrant the collaboration of researchers and advisors for synergies that can be gained in a mixed planting system. The characteristics of the clusters can also help these collaborators know their audience; for example, properties with mixed crops from clusters 2 and 4 were
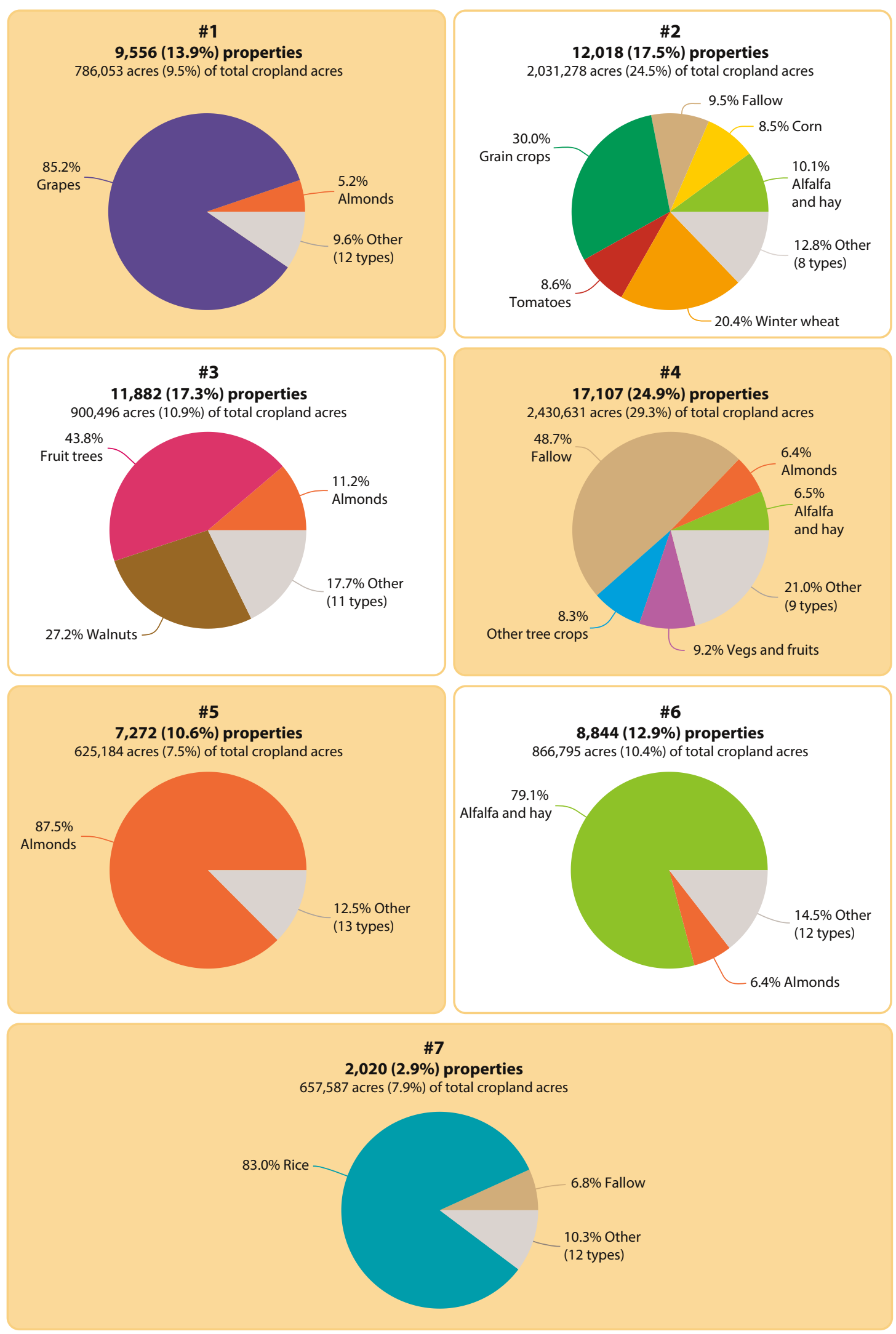

Fig. 4. Hierarchical clustering results based on the average percentages of crop category grown for each owner.
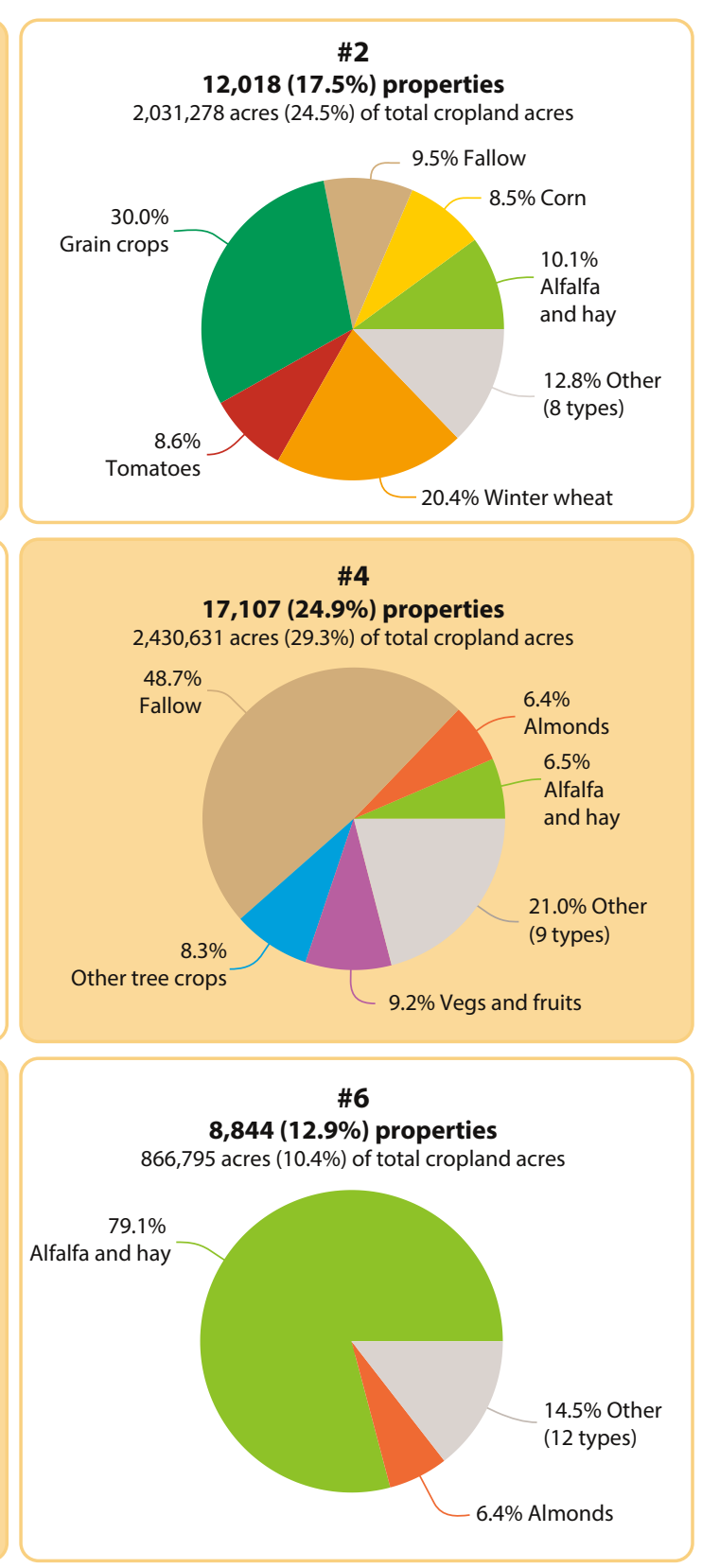

$\mathbf{8 , 8 4 4}(12.9 \%)$ proper

7

2,020 (2.9\%) properties

http://calag.ucanr.edu • OCTOBER-DECEMBER 2017 
larger than the average farm, while the tree crop mix (cluster 3) was composed of smaller properties than average.

The differences in distribution of ownership by different crop types or counties are likely influenced by the suitability of land for particular crops, historical settlement patterns, whether economies of scale are present for growing the crop, and local land use ordinances. Walnuts had small median and mean area planted, which is likely driven by their requirements for high quality alluvial soils that occur along rivers flowing out of the Sierra Nevada. These lands have generally coincided with historic small towns that have been farmed for longer periods of time, leading to greater fragmentation as generations turn over and land holdings are split among family members (UC Agricultural Issues Center 1994a; Dr. Katherine Pope and Dr. David Ramos, UC Agriculture and Natural Resources, personal communication). Much of the state's rice is grown on soils that have such a high clay content that no other crops can be productively grown on them, possibly reducing small-farm demand and subdivision for this type of land (UC Agricultural Issues Center 1994b; Dr. Jim Hill, UC Davis, personal communication). The consolidation of cotton plantings occurred historically and likely is impacted by a variety of factors, including the relative difficulty in growing cotton, its greater ability to grow in saline soils, and economies of scale in producing sufficient cotton to sustain a ginning operation (Dr. Robert Hutmacher, UC Agriculture and Natural Resources, personal communication).

The relative equality of ownership in counties like Santa Clara, Mendocino and Napa counties may be driven by earlier settlement and homesteading patterns where the size of farm was limited by the amount of labor available (usually the immediate family), making large aggregations of acreage more difficult (Glenn McGourty, UC Agriculture and Natural Resources, personal communication). Additionally, Napa County enacted the Agricultural Preserve Act and Measure P, which implements minimum parcel size regulations and zones agricultural use as the best use in many areas of Napa County (Dr. Monica Cooper, UC Agriculture and Natural Resources, personal communication).

These factors have led to comparatively few dominant landowners in these coastal agricultural areas, and in the case of Napa, fewer smallholders, which limits the measure of inequality.

These results provide useful information for Cooperative Extension efforts seeking to target growers by particular crop varieties or by various localities. This assessment can provide help in prioritizing outreach activities and methods of communication, as well as in tailoring research efforts to stakeholders' needs. They may also prove useful in allocating resources regionally depending on the area of cropland, type of crop and number of people served. Continuing to track the relationship between ownership patterns and crop patterns in the future will be a valuable way to analyze the everchanging landscape of agriculture in California. CA

L. Macaulay and V. Butsic are Assistant UC Cooperative Extension Specialists in the Department of Environmental Science, Policy and Management at UC Berkeley.

The authors thank the UC Berkeley Earth Sciences \& Map Library and UC Agriculture and Natural Resources for funding to support this research.

\section{References}

Bigelow D, Borchers A, Hubbs T. 2016. US Farmland Ownership, Tenure, and Transfer. www.ers. usda.gov/publications/pubdetails/?pubid=74675 (accessed Oct. 26, 2016)

Brodt S, Klonsky K, Tourte L. 2006. Farmer goals and management styles: Implications for advancing biologically based agriculture. Agr Syst 89:90-105. CCED [California Conservation Easement Database]. 2015 California Protected Areas Data Portal. www.calands.org/cced (accessed Apr. 28, 2016) CDFFP [California Department of Forestry and Fire Protection] 2014. FRAP - CAL FIRE Ownership Download. http://frap.fire. ca.gov/data/frapgisdata-swownership13_2_download (accessed Apr. 28, 2016).
CPAD [California Protected Areas Database]. 2015. California Protected Areas Data Portal. www.calands.org/data (accessed Apr. 28, 2016).

Ferranto S, Huntsinger L, Getz C, et al. 2013. Management without borders? A survey of landowner practices and attitudes toward cross-boundary cooperation. Soc Natur Resour 26:1082-1100.

Greiner R, Gregg D. 2011. Farmers'intrinsic motivations, barriers to the adoption of conservation practices and effectiveness of policy instruments: Empirical evidence from northern Australia. Land Use Policy 28:257-65.

Jaro MA. 1989. Advances in record-linkage methodology as applied to matching the 1985 census of Tampa, Florida. J Am Stat Assoc 84:414-420.
Macaulay L. 2016. The role of wildlife-associated recreation in private land use and conservation: Providing the missing baseline. Land Use Policy 58:218-33.

Mülner D. 2013. fastcluster: Fast hierarchical, agglomerative clustering routines for $\mathrm{R}$ and $\mathrm{Py}$ thon. J Stat Softw 53. www.jstatsoft.org/article/view/v053i09 (accessed Oct. 18, 2016).

NASA [National Aeronautics and Space Administration] 2015. Federal agencies release data showing California Central valley idle farmland doubling during drought. https://landsat. gsfc.nasa.gov/federal-agenciesrelease-data-showing-california-central-valley-idle-farmlanddoubling-during-drought/ (accessed Mar. 11, 2017).
Sherrick BJ, Barry PJ. 2003 Farmland markets: Historical perspectives and contemporary issues. In: Moss CB, Schmitz A A(eds.). Government Policy and Farmland Markets. Ames, IA: lowa State Press. p 27-49. http://onlinelibrary.wiley.com/ doi/10.1002/9780470384992. ch3/summary (accessed Oct. 18, 2016).

Sunding D, Zilberman D. 2001 The agricultural innovation process: Research and technology adoption in a changing agricultural sector. Chapter 4. In: Handbook of Agricultural Economics. Vol. 1, part A. Gardner BL, Rausser GC (eds.). p 207-61. UC Agricultural Issues Center. 1994a. The Walnut Industry in California: Trends, Issues and Challenges. University of California, Agricultural Issues Center, Davis, Calif. http://aic.ucdavis. edu/publications/CAwalnuts. pdf (accessed Aug. 15, 2016).
UC Agricultural Issues Center. 1994b. Maintaining the competitive edge in California's rice industry. University of California, Agricultural Issues Center, Davis, Calif. https://catalog.hathitrust. org/Record/100799847 (accessed Aug. 15, 2016)

USDA-NASS [USDA National Agricultural Statistics Service]. 2014. 2013 California Cropland Data Layer. www.nass.usda.gov/ Research and Science/Cropland/metadata/metadata_ca13. htm (accessed Oct. 18, 2016).

Winkler WE. 1990. String comparator metrics and enhanced decision rules in the fellegi-sunter model of record linkage. http://eric. ed.gov/?id=ED325505 (accessed Apr. 28, 2016).

Zeileis A. 2014. ineq: Measuring inequality, concentration, and poverty. https://CRAN.R-project. org/package=ineq 